\title{
Forensic Nanotechnology in Forensic Genetics
}

\author{
Niha Ansari ${ }^{1}$, Alok Pandya ${ }^{2}$, Pinkesh Sutariya ${ }^{3}$ and Anand Lodha ${ }^{4 *}$ \\ ${ }^{1}$ Department of Forensic Science, Gujarat University, India \\ ${ }^{2}$ Department of Chemistry, University and Institute of Advanced Research, India \\ ${ }^{3}$ Bhavans Shree IL Pandya Arts-Science College, Gujarat University, India \\ ${ }^{4}$ School of Chemical Sciences, Central University of Gujarat, India
}

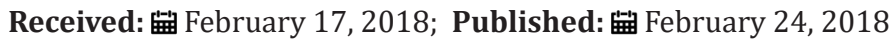

*Corresponding author: Dr. Anand Lodha, School of Chemical Sciences, Central University of Gujarat, India

\begin{abstract}
Deoxyribose Nucleic Acid (DNA) is unique to each and every individual and it remains constant throughout the life as it follows the laws of Mendelian inheritance. However DNA analysis is widely accepted techniques for personal identification. DNA extraction and isolation from ancient bone samples, degraded body parts etc. is still quite difficult and challenging task for forensic scientist. But new upcoming technology like nanotechnology will help for analysis of such samples for DNA. Hence, in this review article we are short listed some of the research articles which used the different nanoparticles for DNA extraction. Where different nanoparticles used for the DNA extraction were cited and explained in brief.
\end{abstract}

Keywords: Nanotechnology; Personal Identification; DNA; Forensic; Nanoparticles; Copper nanoparticles; Gold nanoparticles; Magnetic Nanoparticles

\section{Introduction}

\section{Personal Identification Using DNA}

Traditionally, personal or forensic identification of human remains is done on the basis of fingerprint, odontology or skeletal evidence, facial characteristics, scars, marks, or other special features. In many cases, the methods available does not prove to be useful as the extent of putrefaction or destruction of the remains or decomposition is very high [1]. In the case of mass disasters, terrorist attacks, traffic accidents, wars, fires, explosions, airplane crashes defragmented body, highly decomposed body or severely burnt and other harrowing events personal identification or forensic identification become very difficult for the investigator from skeletal remains [2-4]. During decomposition human body undergoes a series of changes and the rate of degradation may vary due to factors like climate, bacterial growth, and insect and animal scavengers [1]. At this time soft tissues do often get destroyed and dental histories may be absent [2]. In such conditions Deoxyribo Nucleic Acid (DNA) can prove to be the most useful source of identification or a good alternative for identification purposes [2]. Deoxyribose Nucleic Acid (DNA) is responsible for the genetic inheritance and hence the discovery of double helix structure of DNA in 1953 triggered the major impact and headed to remarkable changes in almost all fields of science including forensic investigations. This understanding has been the foundation for development of new techniques and methodologies that permits characterizing each person have individually based on DNA sequence. DNA is composed of phosphate backbone, deoxyribose sugar, and nitrogenous base where the phosphate backbone and deoxyribose sugar remain constant across all individuals, only the nitrogenous bases distinguishes between each individuals. Hence, human DNA consists of 99.9 percent sequences approximately same in each individual only 0.1 percent is found to be different that is unique to each individual, though the possibility of having same DNA is about approximately 10-15 between two unrelated individual $[5,6]$. These minute differences in human DNA sequences can be detected and in 1984 first forensic DNA testing was done on the basis of these differentiations between DNA sequences [7].

In recent years it is largely widespread that, DNA could lead to personal identification of human remains, namely skeletal remains in the majority of the cases. DNA sample identification and profiling play very crucial role in mass disaster and also to identify suspect 
in civil and criminal cases. But simultaneously, it should be taken in to consideration that the degradation of genetic materials by the microorganism, humidity and many organic or inorganic compounds to which the skeletal remains were exposed reduce the amount of DNA and reliability of extraction of good quality DNA. To overcome such problem the use of small size loci amplification by polymerase chain reaction (PCR) gives the excellent results for further analysis of genetic materials. However, in forensic examination of skeletal remains, in context of personal identification, extraction of the PCR ready genetic material has become the crucial and challenging task. For forensic purposes, DNA was routinely isolated from different biological evidences such as blood, saliva, semen, hair, urine, skin, tissues, tooth, bones, etc [8-20]. From all these bone and tooth samples, particularly from ancient/buried/post-mortem skeletal remains samples, examination has been a chal $\neg$ lenging task as the skeletal remains samples bring complication to the DNA extraction process due to the paucity of chemicals used to achieve effective disruption of cells and denature nucleoprotein/ protein-DNA complexes in the embedded cells. In addition, there is non-uniformity of sampling even from pulver $\neg$ ized bone powder, compounded by the generally low quantity of cellular material and age-related degradation of DNA in the bone and the presence of polymerase chain reaction (PCR) inhibitors. Besides DNA hydrolysis by cellular nucleases and microbial degrada $\neg$ tion, the DNA molecules are prone to biochemical degradation such as hydrolytic and oxidaᄀtive damage [21,22].

There are many commercial products available for the isolation of DNA, involving column chromatography or extraction following agarose gel electrophoresis, but these techniques fail to avoid contamination or complicated procedures. It is essential that the isolated DNA from biological samples must be free from any kind of contaminants, such as protein and RNA. The process of genomic DNA isolation and purification has advanced considerably within the last decade but still there is need for improvements in methodologies for the DNA isolation. There is a necessity to replace old laborious and time-consuming traditional techniques which, generally rely on the use of phenol-chloroform method. All these techniques of DNA extraction are time-consuming, multi-step and utilize organic solvent for extraction, alcohol precipitation as well as centrifugation [23]. However, nanotechnology is recently entered in DNA isolation to answer and overcome such problems.

\section{Forensic Nanotechnology}

The advent of nanotechnology is taking control of atoms and molecules individually, modifying and placing them to use with an extraordinary degree of accuracy. The word 'Nano' comes from Greek word means dwarf, which refers to one billionth (10-9) mean about nanometer (nm) [24]. It deals with emerging material or devices having size equal to $100 \mathrm{~nm}$ or lesser. Nanomaterials are applying in different areas including electronics, engineering, physical sciences, materials sciences and also found its application in the field of medical science [25]. The advancement of nanotechnology has led to the development of newer methods which are novel and have improved properties which prove to be valid in all areas of science and technology. At present nanotechnology is playing vivacious role in the field of biomedical and biological fields [26,27].

Currently, nanoparticles have gained a huge attention for analytical biochemistry, medicine, and biotechnology applications, due to their unique size and physical properties. In the context of bio-separation and purification, a probable solution is to replace micro-particle with nanoparticles as they have high surface to volume ratio. Advancement of integrated systems to isolate DNA are developed which employ solid-phase supports among which magnetic nanoparticles have received great attention due to their easy manipulation and cost-effectiveness [28]. Magnetic nanoparticles has become an increasingly popular technique for the separation of biomolecules namely proteins, DNA and RNA [29]. Magnetic particles have been successfully used to extract genomic DNA from body fluids, such as blood, saliva, and semen [30]. Magnetic particles coated with different polymers like agarose, carboxyl and silica have been studied for DNA isolation [31]. Solid phase systems which adsorb DNA - silica-based particles, glass fibers, anion-exchange carriers, and modified magnetic beads have been used as they have an advantage of minimum DNA degradation during its purification [32-41].

From blood DNA extraction was done using magnetic nanoparticles by ZM Saiyed et al. [40], using magnetic microsphere by Rui Gong et al. [41] and ZM Saiyed et al. [42], from cell culture using magnetic nanoparticles by ZM Saiyed et al. [42] and using salicylic acid-coated magnetic nanoparticles by Zhongwu Zhou et al. [43], from soil using silica-magnetic nanoparticles by $\mathrm{A}$ Sebastianelli et al. [44], from urine using magnetic nanoparticles by Zhi Shan et al. [45] and from saliva using magnetic nanoparticles by Li Yi et al. [46]. The phenol / chloroform method is toxic, timeconsuming, and multi-step and utilizes organic solvent extraction, alcohol precipitation, as well as centrifugation [47]. The method has limitation while dealing with small amounts of DNA. The use of magnetic carrier technology has become widespread technique for the separation of biomolecules such as DNA, RNA and proteins $[48,49]$.

Lodha et al. [50] utilized the unique property of copper nanoparticles for DNA isolation from skeletal remains samples for the first time ever. Where copper nanoparticles synthesized in microwave by using diethylene glycol (DEG), ascorbic acid and Poly Vinyl Pyrrolidone (PVP), which binds to DNA with very high affinity. The novelty of this method is that the copper nanoparticles have not been applied till now for DNA isolation. Moreover, authore claimed that this developed method can easily be applied to DNA isolation from skeletal remains. Muntaha et al. [51] found that 
the improvement of DNA quality and quantity were obtained when DNA extracted from Gram negative bacteria by extraction methods (boiling, alkali lysis and salting out) in the presence of $\mathrm{ZnO}$ nanoparticles. While in the presence of $\mathrm{TiO} 2$ nanoparticles, improvement in DNA quantity extraction from both bacteria was obtained when it had been used the salting out method only. Kwang et al. [52] used the longitudinal resonance of Au nanorods to transform near infrared energy into thermal energy in a microfluidic chip. Where the resulting heat generated effectively caused pathogen lysis. Consequently the DNA was extracted out of the cell body and transferred to a PCR system. Which resulted in the successful demonstration of a one step real-time PCR system for pathogen detection without removal or changing of reagents?

\section{Conclusion}

The use of nanotechnology to identify unknown human remains using forensic genetics/DNA has the potential to provide precise personal identification in portable, nonhazardous, easy manner from even trace samples. It is imperative that DNA extraction efficiency is maximized for forensic analyses because sample sizes are often limited and incomplete DNA extractions can introduce bias and therefore alter the interpretation of results. The reproducibility and nanomaterials used in the extraction steps requires research. Due to the existence of a wide variety of nanomaterials based DNA extraction protocols, there is currently no standardized extraction method used across forensic laboratories. This may limit the potential to compare forensic samples across different forensic research and lab groups, countries, or even case studies. Lastly, standardization of nanomaterials based lab on chip DNA forensic methods will need to be examined. When these issues are resolved, forensic scientists will be able to incorporate nanomaterials and DNA analysis into commonly applied casework, providing robust, reliable evidence for personal identification using nanotechnology.

\section{References}

1. LC Richard (2009) Thesis University of Indiana University Purdue.

2. J Ye, Ji EJ, Parrg X, Zheng C, Jiang, et al. (2004) Tu J Forensic Sci 49 : 754 759.

3. MM Hasan, T Hossain, AK Majumder, P Momtaz, T Sharmin, et al. (2014) Dhaka Univ J Biol Sci (23): 101-107.

4. J Jakubowska, A Maciejewska, R Pawłowski (2012) Comparison of three methods of DNA extraction from human bones with different degrees of degradation. Int J Legal Med 126(1): 173-178.

5. DA Schultz (2009) The Encyclopedia of American Law. Infobase Publishing.

6. RE Gaensslen, HA Harris, HC Lee (2007) Introduction to Forensics \& Criminalistics. Mc Graw Hill Companies Inc, USA.

7. MA Luftig, S Richey (2001) New England law review 35: 609-613.

8. S Ghatak, RB Muthukumaran, SK Nachimuthu (2013) A Simple Method of Genomic DNA Extraction from Human Samples for PCR-RFLP Analysis. Journal of Biomolecular Techniques 24(4): 224-231.
9. DK Lahiri, B Schnabel (1993) DNA isolation by a rapid method from human blood samples: Effects of $\mathrm{MgCl} 2$, EDTA, storage time, and temperature on DNA yield and quality. Biochemical Genetics 31: 321328.

10. RW Cone, ML Huang, R Ashley, L Corey, (1993) Human herpesvirus 6 DNA in peripheral blood cells and saliva from immunocompetent individuals. J Clin Microbiol 31(5): 1262-1267.

11. DJ Walsh, AC Corey, RW Cotton, L Forman, G L Herrin, et al. (1992) Isolation of deoxyribonucleic acid (DNA) from saliva and forensic science samples containing saliva. J Forensic Sci 37: 387-395.

12. NW Schwark, V Malyusz, H Fremdt, C Koch, T Schwark (2006) International Congress Series 1288: 565-567.

13.J Griffin (2013) Methods of sperm DNA extraction for genetic and epigenetic studies. Methods Mol Biol 927: 379-384.

14. Z Guan, Y Zhou, J Liu, X Jiang, S Li (2013) A Simple Method to Extract DNA from Hair Shafts Using Enzymatic Laundry Powder PLoS ONE 8: e69588.

15. LE Bali, A Diman, A Bernard, NHC Roosens, SCJD Keersmaecker (2014) Comparative study of seven commercial kits for human DNA extraction from urine samples suitable for DNA biomarker-based public health studies. Biomol Tech 25(4): 96-110.

16. JV Sidorova, BV Biderman, EE Nikulina, AB Sudarikov (2012) A simple and efficient method for DNA extraction from skin and paraffinembedded tissues applicable to T-cell clonality assays. Exp Dermatol 21(1): 57-60.

17. JMS Bartlett, D Stirling(2003) A short history of the polymerase chain reaction. PCR Protocols Methods in Molecular Biology, Human Press 226: 33-34.

18. R Gaytmenn, D Sweet (2003) J Forensic Sci 48: 622-625.

19.Z Presecki, H Brkic, D Primorac, I Drmic (2000) Perception of Forensic Odontology and its Practice among the Local Dentists of an Institution . ActaStomatol Croat 34: 21-24.

20. PV Mandrekar, L Flanagan, A Tereba (2002) Improved performance for forensic casework: Extraction and isolation updates for the Maxwell 1 16 instrument Profiles in DNA. 5: 11-13.

21. T Lindahl(1993) Instability and decay of the primary structure of DNA. Nature 362: 709-715.

22. JG Shewale, RH Liu (2013) Forensic DNA Analysis: Current Practices and Emerging Technologies, CRC Press, Taylor and Francis, USA.

23. A Bandyopadhyay, S Chatterjee, K Sarkar (2011) Current science 101: 210-214.

24.V Labhasetwar, DL Pelecky (2007) Biomedical Applications of Nanotechnology. Wiley, New York, USA.

25. OV Salata (2004) Journal of Nanobiotechnology 2: 1-6.

26. JH Min, MK Woo, HY Yoon, J WJang, JH Wu (2014) Isolation of DNA using magnetic nanoparticles coated with dimercaptosuccinic acid. Analytical Biochemistry 447: 114-118.

27. GK Kouassi, J Irudayaraj (2006) Magnetic and Gold-Coated Magnetic Nanoparticles as a DNA Sensor. Anal Chem 78: 3234-3241.

28.Z Shan, Z Zhou, H Chen, Z Zhang, Y Zhou, et al. (2012) Journal of Chromatography B (881- 882): 63- 68.

29. R Boom, CJA Sol, MMM Salimans, CL Jansen, PME Wertheim van Dillen, et al. (1990) Rapid and simple method for purification of nucleic acids. J Clin Microb 28: 495-503. 
30. KA Melzak, CS Sherwood, RFB Turner, Ch A Haynes (1996) Adsorption and elution characteristics of nucleic acids on silica surfaces and their use in designing a miniaturized purification unit. J Colloid Interface Sci 181: 635-644.

31. H Tian, AFR Huhmer, JP Landers (2000) Anal Biochem 283: 175-191.

32. MC Breadmore, KA Wolfe, IG Arcibal, WK Leung, D Dickson, et al. (2003) Anal Bioche 75: 1880-1886.

33. GNM Ferreira, JMS Cabral, DMF Prazeres (2000) Biotechnol Prog 16: 416-424.

34. E Thwaites, SC Burton, A Lyddiatt, J Chromatogr (2002) 943: 77-90.

35. HN Endres, JAC Johnson, CA Ross, JK Welp (2003) Biotechnol App Biochem 37: 259-266.

36. MA Teeters, SE Conrardy, BL Thomas, TW Root, EN Lightfoot (2003) Adsorptive membrane chromatography for purification of plasmid DNA. 989: 165-173.

37. PR Levison, SE Badger, J Dennis, P Hathi, MJ Davies (1998) 816: 107-111

38. PR Levison, SE Badger, P Hathi, MJ Davies, IJ Bruce (1998) New approaches to the isolation of DNA by ion-exchange chromatography. 827(2): 337-344

39. J Prodelalova, B Rittich, A Spanova, K Petrova, MJ Benes (2004) 1056: 43-48.

40. ZM Saiyed, CN Ramchand (2007) Extraction of Genomic DNA Using Magnetic Nanoparticles $\left(\mathrm{Fe}_{3} \mathrm{O}_{4}\right)$ as a Solid-Phase Support. Am J Infect Dis 3(4): 225-229.

41. R Gong, L Shengying (2014) Int J Nanomedicine Extraction of human genomic DNA from whole blood using a magnetic microsphere method 9: 3781-3789.

42. ZM Saiyed, CN Ramchandand, SD Telang (2008) J Phys Condens Matter 20: 1-5.
43. Z Zhou, US Kadam, J Irudayaraj (2013) One-stop genomic DNA extraction by salicylic acid-coated magnetic nanoparticles. Anal Biochem 442(2): 249-252.

44. A Sebastianelli, T Sen, IJ Bruce (2008) Extraction of DNA from soil using nanoparticles by magnetic bioseparation. Lett ApplMicrobiol 46(4): 488-491.

45. Z Shana, Z Zhou, H Chen, Z Zhang, Y Zhou, (2012) J Chromatogr B (881882): 63-68.

46. L Yi, Y Huang, T Wu, J Wu (2013) A magnetic nanoparticles-based method for DNA extraction from the saliva of stroke patients. Neural Regen Res 8(32): 3036-3046.

47. J Sambrook, D Russell (2001) Molecular Cloning: a Laboratory Manual ( $3^{\text {rd }}$ edn); Cold Spring Harbor NY Cold Spring Harbor Laboratory.

48. PJ Robinson, P Dunnill, MD Lilly (1973) The properties of magnetic supports in relation to immobilized enzyme reactors. Biotechnol Bioeng 15(3): 603-606.

49. M Magnani, L Galluzzi IJ Bruce (2006) The use of magnetic nanoparticles in the development of new molecular detection systems. J Nanosci Nanotechnol 6: 2302-2311.

50. A Lodha, A Pandya, RK Shukla (2016) Nanotechnology: An Applied and Robust Approach for Forensic Investigation. Forensic Res CriminolInt J 2(1): 00044.

51. RA Muntaha, Majid HA, Ayad MA, Shaymaa RA (2015) Intl Conf on J Medical Genetics, Cellular \& Molecular Biology, Pharmaceutical \& Food Sciences Istanbul.

52. KH Cheong, DK Yi, JG Lee, JM Park, MJ Kim (2008) Gold nanoparticles for one step DNA extraction and real-time PCR of pathogens in a single chamber. Lab Chip 8(5): 810-813.

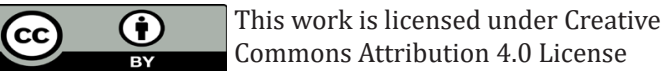

To Submit Your Article Click Here: Submit Article

DOI: 10.32474PRJFGS.2018.01.000107

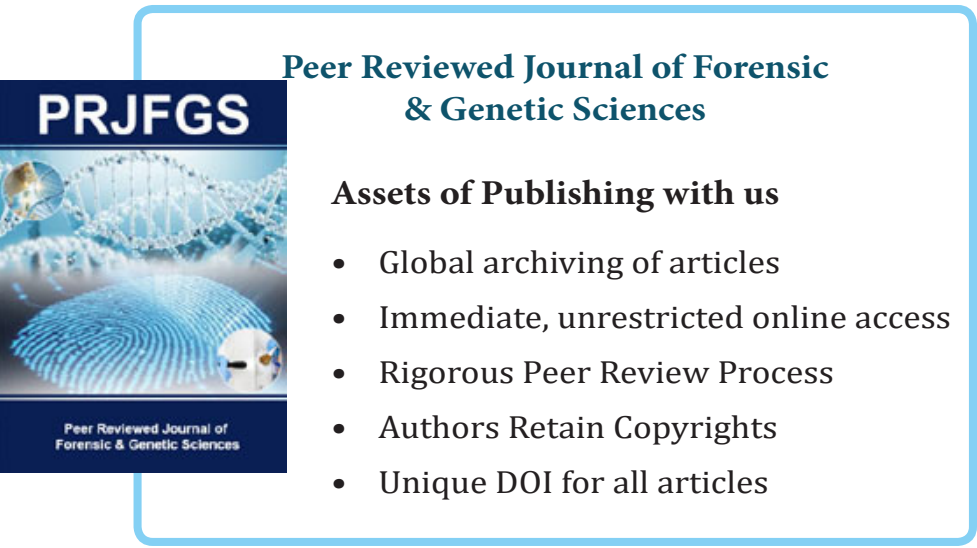

